\title{
Electrocatalytic Reduction of Oxygen at Perovskite (BSCF)-MWCNT Composite Electrodes
}

\author{
Farhanini Yusoff', Norita Mohamed ${ }^{1}$, Azizan Aziz², Sulaiman Ab Ghani1 ${ }^{*}$ \\ ${ }^{1}$ Pusat Pengajian Sains Kimia, Universiti Sains Malaysia, Georgetown, Malaysia \\ ${ }^{2}$ Pusat Pengajian Kejuruteraan Bahan \& Sumber Mineral, Universiti Sains Malaysia, Georgetown, Malaysia \\ Email: ${ }^{*}$ sag@usm.my
}

Received 13 December 2013; revised 19 January 2014; accepted 6 February 2014

Copyright (C) 2014 by authors and Scientific Research Publishing Inc.

This work is licensed under the Creative Commons Attribution International License (CC BY). http://creativecommons.org/licenses/by/4.0/

(c) (7) Open Access

\begin{abstract}
A composite paste electrode based on $\mathrm{Ba}_{0.5} \mathrm{Sr}_{0.5} \mathrm{Co}_{0.8} \mathrm{Fe}_{0.2} \mathrm{O}_{3-\delta}$ (BSCF)-initially synthesized by solgel method-and multiwall carbon nanotube (MWCNT) as a cathode in fuel cells is developed. The composite pastes are prepared by the direct mixing of BSCF:MWCNT at 90:10, 80:20 and 70:30 (\% $w / W)$. These electrodes are then characterized by the x-ray diffraction (XRD), scanning electron microscopy (SEM), nitrogen adsorption-desorption isotherm, electrochemical impedance spectroscopy (EIS) and cyclic voltammetry (CV). The XRD and SEM confirm the inclusion and the uniform dispersal of the MWCNT within BSCF, respectively. The nitrogen adsorption isotherm study shows that the porosity of the composite paste electrode has been improved by two-fold from the BSCF electrode. The EIS and CV demonstrate that the higher ratios of MWCNT in the composites are critical in improving the electronic conductivity as well as the kinetics. It is also noticeable that the electrode has increased the catalysis of oxygen in $0.1 \mathrm{M} \mathrm{KOH} \mathrm{(pH} \mathrm{12.0).} \mathrm{Cyclic} \mathrm{voltammetric}$ studies on the oxygen reduction reaction (ORR) suggest that the incorporation of MWCNT is vital in improving the electrode (cathode) properties of a fuel cell.
\end{abstract}

\section{Keywords}

$\mathrm{Ba}_{0.5} \mathrm{Sr}_{0.5} \mathrm{Co}_{0.8} \mathrm{Fe}_{0.2} \mathrm{O}_{3-\delta}$ (BSCF); Catalysis; Composites; Multiwall Carbon Nanotube (MWCNT); Oxygen Reduction Reaction

\section{Introduction}

Although the oxygen reduction reaction (ORR) is important in variety of electrochemical processes including corrosion inhibition and metal-air batteries, the application of the ORR in fuel cells is of particular interest

"Corresponding author. 
[1]-[3]. In the fuel cell the electro catalytic ORR at various electrode materials have been reported [4]-[10]. The electrode process may involve either 2 or 4 electrons depending on the electrode material used [11]-[14]. This reaction, however, requires the use of platinum as the catalyst, which then contributes to the high cost of these fuel cells. Highly active transition-metal-oxides such as perovskite-type oxides, $\mathrm{ABO}_{3}$, have been used as catalysts in fuel cells [15] [16] and are operable at room temperature [17] [18]. By improving its electronic properties, the perovskite materials can be used as catalyst for low temperature fuel cell and metal air-batteries [19] [20].

The $\mathrm{Ba}_{0.5} \mathrm{Sr}_{0.5} \mathrm{Co}_{0.8} \mathrm{Fe}_{0.2} \mathrm{O}_{3-\delta}$ (BSCF) is known to have a high oxygen vacancy concentration. It has exhibited the highest oxygen evolution reaction (OER) activity [21]. This is due to the high occupancy of the 3d electrons with an $\mathrm{e}_{\mathrm{g}}$ symmetry of the transition metal cations in an oxide. Accordingly, BSCF has been proposed as the electrodes in rechargeable metal-air batteries and regenerative fuel cells. However, the application of BSCF for the ORR in aqueous media at room temperature has never been investigated.

It is generally accepted that nanomaterials with high surface area could maximize the surface activity to improve the reaction kinetics of electrode materials, and afford a short distance for ionic mass and charge transportation, which resulted in higher electrochemical reaction. Multiwall carbon nanotube (MWCNT) is known to facilitate the electron transfer process especially in biosensor fabrications [22] [23]. MWCNT has also been employed as a useful material to modify electrode surface in order to enhance the electrochemical response [24][27]. The combined effects of the high specific surface area and good electrical conductivity make MWCNT as a good choice as an electrode material [28] [29].

To the best of our knowledge, the composite of BSCF and MWCNT has not yet been exploited as an electrode for ORR purposes. This report describes the preparation and characterization of BSCF and its composite (BSCF-MWCNT) electrodes and also their applications for ORR at the room temperature.

\section{Materials and Methods}

\subsection{Reagents and Equipment}

The MWCNT ( 8 - $15 \mathrm{~nm}$ OD, $50 \mu \mathrm{m}$ length, purity >95\%) was purchased from Chengdu Organic Chemicals Co. Ltd., Chinese Academy of Sciences, China. Ethylene diaminetetraacetic acid (EDTA), potassium ferrocyanide (99.0\%), potassium chloride (99.0\%), anhydrous citric acid and nitrate salts of barium (II), strontium (II), cobalt (II) and iron (III), potassium hydroxide, were purchased from Sigma Aldrich, USA and were used as received. Ammonia solution was purchased from Systerm Chemicals, Australia. Aqueous solutions were prepared with the water from Millipore Direct-Q3 (18.2 M $\Omega \mathrm{cm})$ of Millipore, USA.

$\mathrm{X}$-ray diffraction (XRD) measurements were performed using an X-ray diffractometer, Siemens-D5000, Germany. The surface morphologies of the samples were characterized by the field emission scanning electron microscopy (FESEM) LEO SUPRA 55VD ultra-high resolution of Zeiss, Germany. The Brunauer-EmmettTeller (BET) surface area and porosity properties were measured using multi point BET Quantachrome surface area analyzer of NovaWin 32, USA. Electrochemical measurements were carried out on Potentiostat/ Galvanostat EG \& G Model 273A (Princeton Applied Research, USA) complete with the Power Suite program. Platinum wires and an $\mathrm{Ag} / \mathrm{AgCl}(3.0 \mathrm{M} \mathrm{KCl})$ served as the working, the auxiliary and the reference electrodes, respectively. Electrochemical impedance spectroscopic (EIS) measurements were carried out using an EG\&G Frequency Response Detector 100 with ZSimpWin 3.22 software of Princeton Applied Research, USA at a frequency range of $100 \mathrm{kHz}$ to $100 \mathrm{mHz}$ and AC voltage amplitude $5 \mathrm{mV}$.

\subsection{BSCF and MWCNT Powder Preparation}

The BSCF precursor powders was prepared using a sol-gel method which was adapted from the literature [30]. The powders produced was then calcined at $1000^{\circ} \mathrm{C}$ and ball-milled for 10 hours. The MWCNT was purified by the sonication in $6 \mathrm{molL}^{-1} \mathrm{HCl}$ for $4 \mathrm{~h}$. Later, $50 \mathrm{mg}$ of purified MWCNT was dispersed in a $40 \mathrm{~mL}$ mixture of $\mathrm{H}_{2} \mathrm{SO}_{4}$ and $\mathrm{HNO}_{3}$ (v:v = 3:1) prior to the further sonication in a water bath for $7 \mathrm{~h}$ at $40^{\circ} \mathrm{C}$. After cooling upto an ambient temperature, the MWCNT was centrifuged and washed to neutral. This pretreatment was subsequently repeated over and again until all the acids are removed. The final solid was then dried to a constant weight. 


\subsection{Electrode Preparation}

BSCF-MWCNT composite paste electrode was prepared by hand-mixing BSCF powder and functionalized MWCNT powder with 90:10, 80:20 and 70:30 (w:w) ratio. Appropriate amount of the mineral oil was added and served as a binder. The mixture was homogenized thoroughly prior to packing into a Teflon tube (4 mm id). A copper wire was then inserted into the opposite end of the cathode to establish an electrical contact. The surface was smoothed on a weighing paper. For comparison purposes, the BSCF and MWCNT paste electrodes were also prepared using the same method.

\subsection{Procedure}

The surface area of the modified, pure BSCF and MWCNT electrodes were analyzed by cyclic voltammetry in the applied potential region of -0.2 to $0.8 \mathrm{~V}$ vs Ag/AgCl in ferricyanide solutions at various scan rates. For ORR activity, cyclic voltammetric experiments were carried out in $15 \mathrm{~mL} 0.1 \mathrm{M} \mathrm{KOH}$ which has been deaerated by purging $\mathrm{N}_{2}$ gas into the solution for $10 \mathrm{~min}$. Later, the similar experiments were done by purging $\mathrm{O}_{2}$ gas for 10 min. These were scanned several times in the applied potential range of -1.1 to $0.2 \mathrm{~V}$ to obtain the stable responses. The aqueous solutions at different $\mathrm{pH}$ values were prepared; $0.1 \mathrm{M} \mathrm{H}_{2} \mathrm{SO}_{4}(\mathrm{pH} 1.0), 0.1 \mathrm{M} \mathrm{H}_{2} \mathrm{SO}_{4}+$ $0.1 \mathrm{M} \mathrm{KOH}\left(\mathrm{pH} 2.0\right.$ - 3.0), $0.2 \mathrm{M} \mathrm{CH}_{3} \mathrm{COOH}+0.2 \mathrm{M} \mathrm{CH}_{3} \mathrm{COONa}\left(\mathrm{pH} 4\right.$ - 5), and $0.1 \mathrm{M} \mathrm{NaH}_{2} \mathrm{PO}_{4}+0.1 \mathrm{M}^{2}$ $\mathrm{KOH}(\mathrm{pH} 6.0$ - 12.0). The $\mathrm{pH}$ of the solutions were adjusted by adding suitable quantities of an acid or alkali and checking the $\mathrm{pH}$ of the medium using a $\mathrm{pH}$ meter.

\section{Results and Discussion}

\subsection{Phase Determination}

The structural characteristics of the as-prepared BSCF-MWCNT composite have been examined via XRD (Figure 1). The single-phase of the pure BSCF is identified without any noticeable second-phase peaks (Figure 1(a)). It is indexed using a cubic $\mathrm{ABO}_{3}$ perovskite-type structure and is in good match with the published data [31] [32]. The BSCF has high crystalinity as shown by the sharp peaks present. However, with the addition of MWCNT, the peaks become broader indicating transformation to polycrystalline structure (Figures 1(c)-(e)). This happens due to the scattering of X-rays in many directions leading to a large bump distributed in a wide range of $2 \theta$. A new peak is detected at a $2 \theta$ value of $25.8^{\circ}$ which is assigned to (002) diffractions corresponding to the interlayer spacing of the nanotube. This proves the presence of MWCNT and is in good agreement with the previous work [33].

It is noticeable that a higher ratio of MWCNT used in the composite results in a (002) peak with higher intensity. It is also observed that the intensity of BSCF diffraction peaks decreases with the increases of the mass ratio of MWCNT to BSCF. A small shift of the BSCF peaks at $2 \theta$ of $47.2^{\circ}(100)$ to a lower diffraction angles $\left(45^{\circ}\right)$ have been observed which is due to the incorporation of the MWCNT into the composite structure. The peak is attributed to the 101 diffraction of functionalized MWCNT. The XRD pattern of the functionalized MWCNT (Figure 1(b)) also confirms the assignment of this peak. The BSCF-MWCNT crystallite sizes of 174,165 and $149 \AA$ are obtained for the BSCF-MWCNT ratio of 90:10, 80:20 and 70:30, respectively. As the BSCF's actual crystallite size is $659 \AA$, the reduction in the crystallite size can be attributed to the presence of functional groups on the MWCNT surface which hinders the crystallization process.

\subsection{Surface Morphology}

The method of preparation of ceramic material is known to affect the particle size, structure, porosity and connection between the particles. The sol-gel method is more preferred for obtaining the porous particles. The synthesis produces homogeneous material composed of uniform particles. An electrode of sufficient porosity is important for ORR to allow rapid transport of the gaseous reactants and to provide abundant sites for the electrochemical reactions.

The BSCF formed from the sol-gel synthesis route are coarse and round-shaped with the particle diameters of $>5 \mu \mathrm{m}$ (Figure 2(a)). High sintering temperatures $\left(\mathrm{T}>1000^{\circ} \mathrm{C}\right.$ ) during the synthesis of BSCF resulted in a decreased surface area. The incorporation of MWCNT resulted in the fibrous-like particles with a higher surface area (Figure 2(c)). This result is further confirmed by the nitrogen adsorption study. The MWCNT tend to 


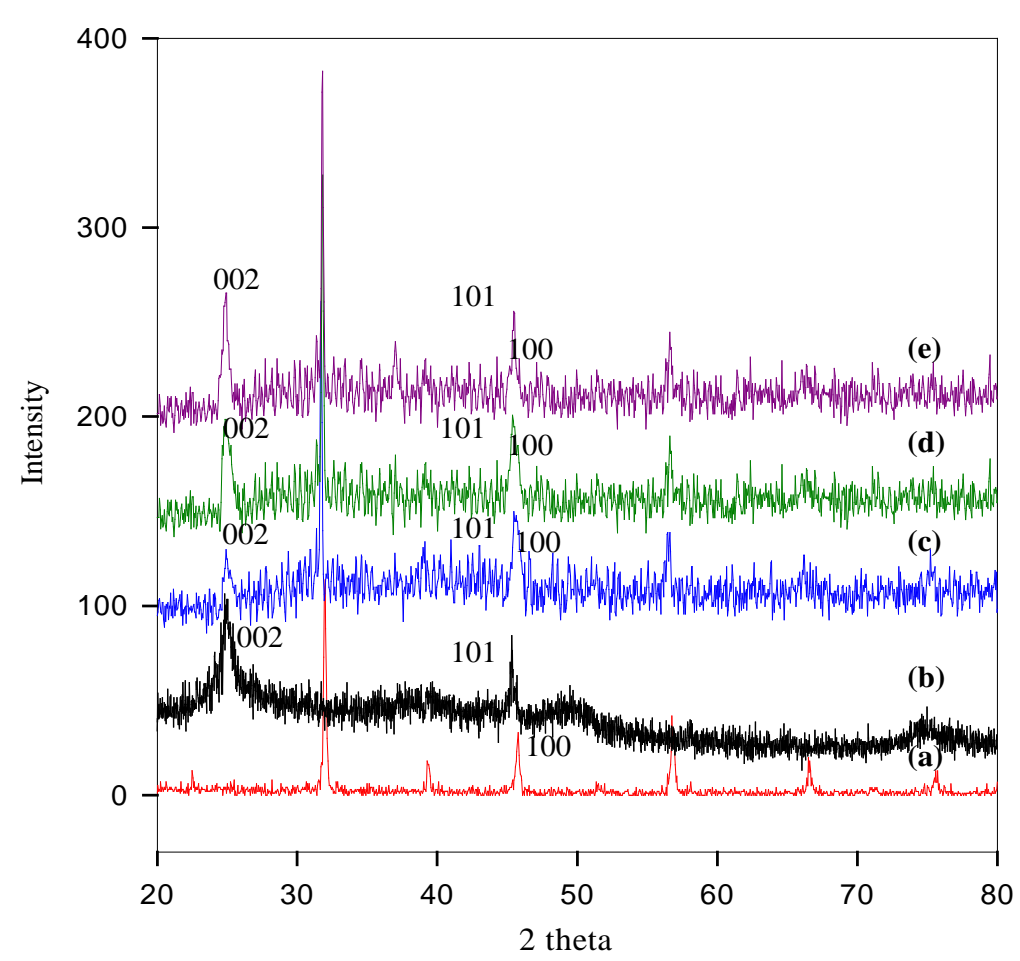

Figure 1. XRD results of (a) BSCF; (b) MWCNT; (c) BSCF-MWCNT 90:10; (d) BSCF-MWCNT 80:20; (e) BSCF-MWCNT 70:30 prepared by direct mixing method.
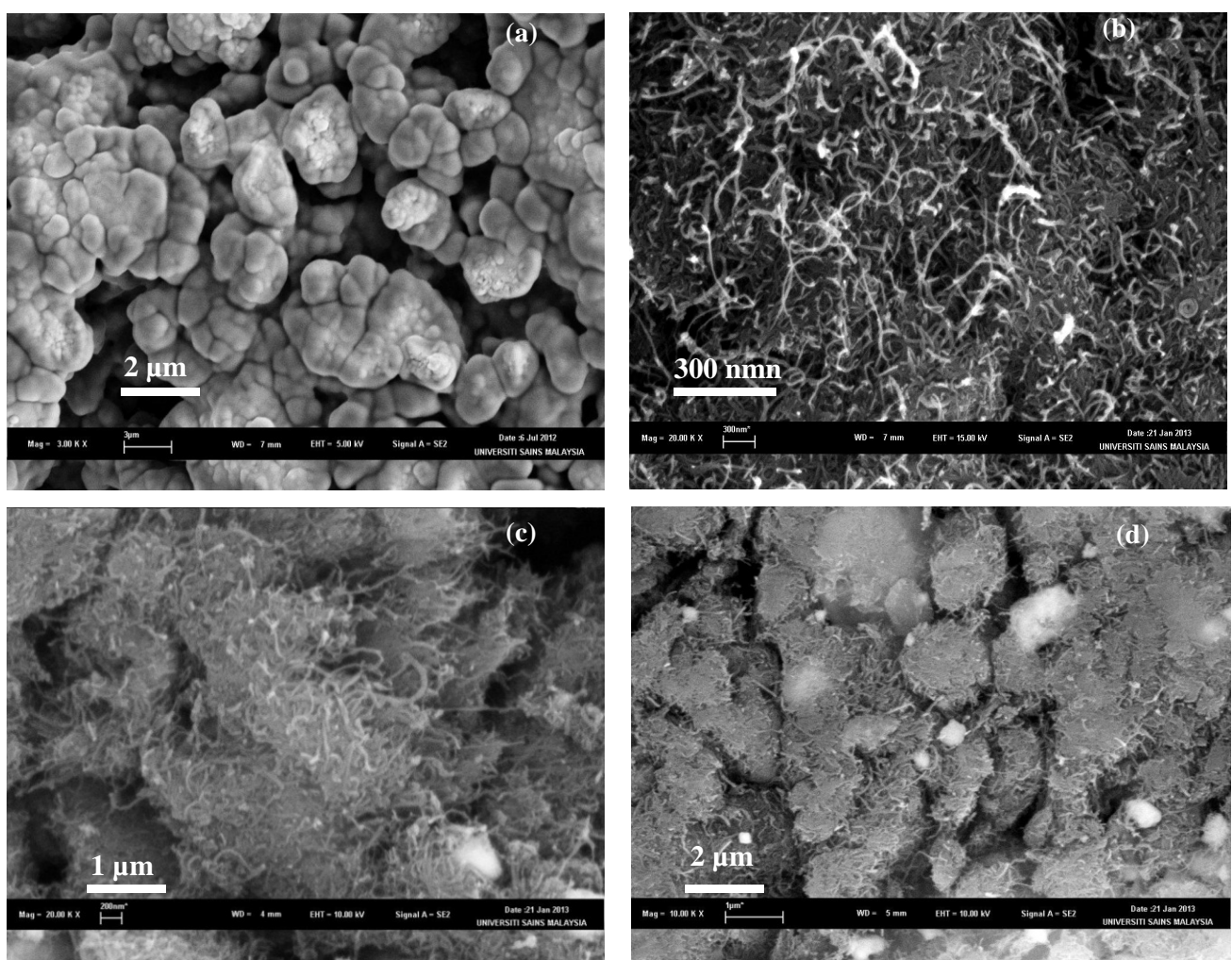

Figure 2. SEM results of (a) BSCF; (b) MWCNT; (c) BSCF-MWCNT at 20× magnification; (d) BSCFMWCNT at $10 \times$ magnification. 
homogenously attach on the external surface of the BSCF and dispersed uniformly without an aggregation. The morphology can be described as a uniform layer of MWCNT covering the BSCF surface completely. This suggests that the direct mixing is sufficient in dispersing the MWCNT within BSCF. A uniform dispersion ensures a non-disrupt conduction within the electrode. Figure 2(d) indicates the successful modification of the BSCF with MWCNT in forming a conductive porous matrix. A porous fibrous network of composites MWCNT is beneficial for the electrolyte access to the active material [34].

\subsection{Adsorption Study}

The porosity of the composites is further studied by nitrogen adsorption-desorption isotherms. The measurements were carried out at $77 \mathrm{~K}$ with a subtracting pore effect (SPE) method using high-resolution $\alpha$ s plots. In Figure 3(a), the BSCF exhibits type-IV Brunauer-Emmett-Teller (BET) sorption characteristics with IUPAC type $\mathrm{H} 3$ hysteresis loop. This is the characteristic of the solids with aggregates or agglomerates of particles forming a slit shaped pores with non-the uniform sizes and shapes. The presence of the micropores is expected from the sudden increase at $\mathrm{P} / \mathrm{P}_{\mathrm{o}}<0.01$. However, after the addition of MWCNT (Figure 3(b)) the isotherm changes to type II with $\mathrm{H} 1$ hysteresis loop together with a higher adsorption volume, which qualitatively translates to an increase of pore volume in the BSCF-MWCNT composites. The H1 hysteresis loop arises due to the capillary condensation of the gas in the mesopores, indicating the transition from the adsorption to the condensation of nitrogen near the saturation vapor pressure [35].

It also implies to the cylindrically shaped pores. This shows that the presence of MWCNT changes the sorption behaviour of the composites. The hysteresis on isotherm curves of the BSCF and BSCF-MWCNT composites

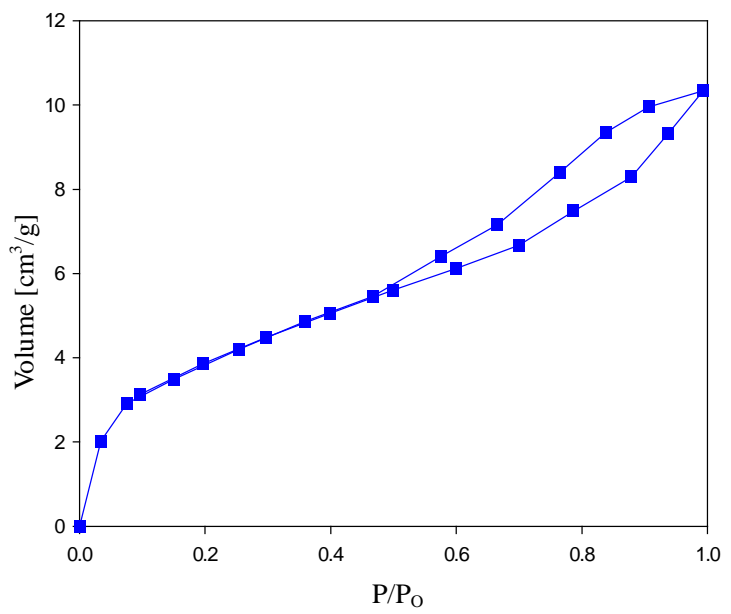

(a)

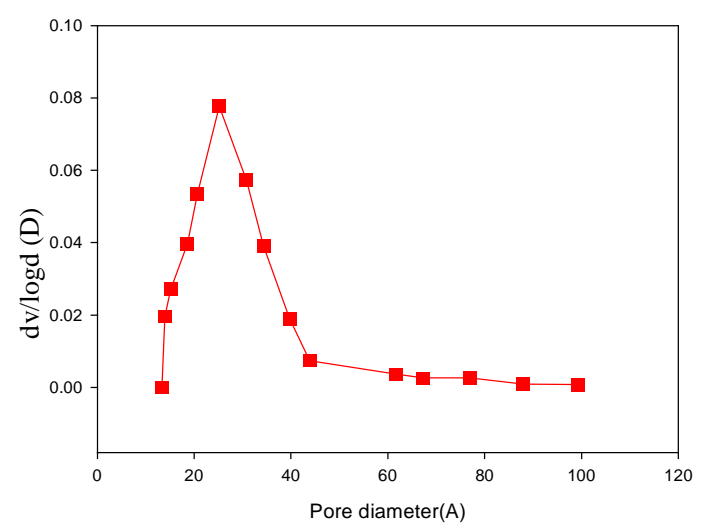

(c)

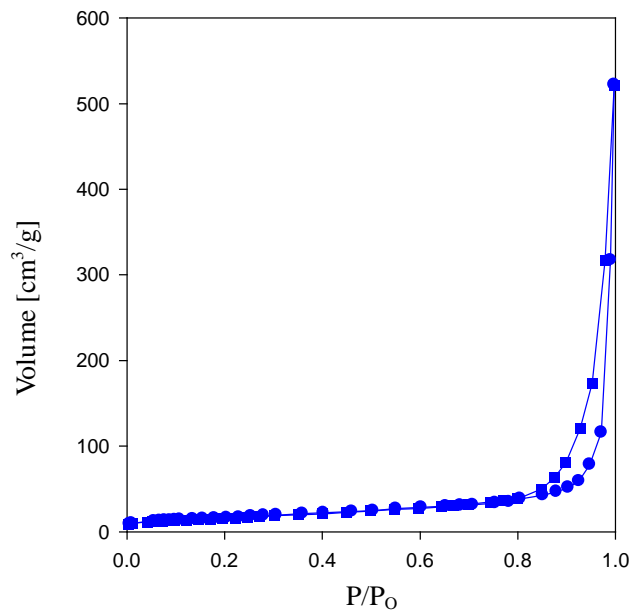

(b)

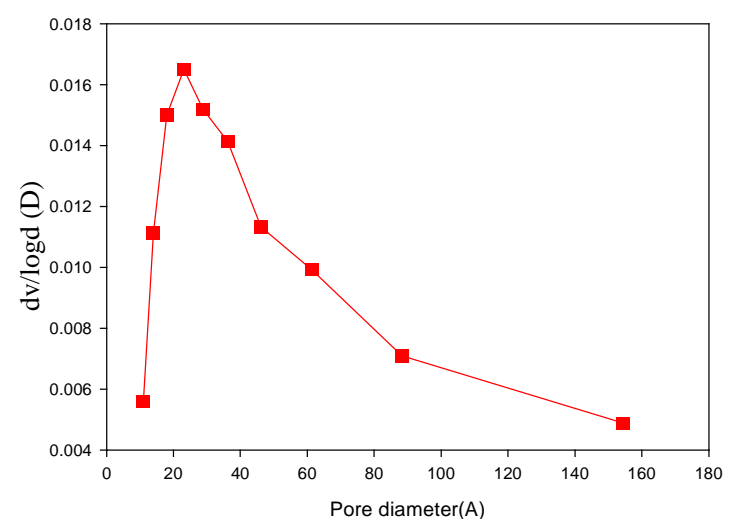

(d)

Figure 3. Nitrogen adsorption/desorption isotherms of (a) BSCF; (b) BSCF-MWCNT and Pore-size distribution curves of (c) BSCF; (d) BSCF-MWCNT. 
suggest the mesoporous structures with lower BET area for BSCF. The larger hysteresis loop of the composites when compared to the BSCF alone indicates an enhanced mesoporosity.

A BSCF-MWCNT composite shows a similar adsorption type to MWCNT as reported [36] [37]. The gradual uptake of nitrogen at the medium $\left(\mathrm{P} / \mathrm{P}_{0}\right)$ and an increase in the adsorption of nitrogen at higher $\mathrm{P} / \mathrm{P}_{0}$ by BSCF-MWCNT composites can be associated with the multilayer adsorption on the external surface and in the larger mesopores formed in the spaces between the particles [38]. The nitrogen adsorption of the BSCF at $\mathrm{P} / \mathrm{P}_{\mathrm{o}}<$ 0.8 may be inferred to the existence of smaller pore volumes.

The pore size distributions of BSCF (Figure 3(c)) and BSCF-MWCNT (Figure 3(d)) composites are calculated using the Barrett-Joyner-Halenda (BJH) analysis of the desorption branch. The mesopore volume was calculated by subtracting the micropore volume from the total pore volume, which was determined from the amount of nitrogen adsorbed at $\mathrm{P} / \mathrm{P}_{\mathrm{o}}=0.98$. The BSCF has a wider pore size distribution i.e. $1-10 \mathrm{~nm}$ which may be contributed to the intra-particle cavities. After modification with the MWCNT, the peak intensity increases with the decrease in the pore size distribution i.e. 1 - $4 \mathrm{~nm}$, suggesting a more uniform pore size. The $\mathrm{BJH}$ analysis for the pore size distributions further indicate that the BSCF and BSCF-MWCNT are essentially made up of mesopores.

Information on pore parameters is summarized in Table 1 . The specific surface areas $\left(\mathrm{S}_{\mathrm{BET}}\right)$, calculated by the BET equation, increase with the presence of MWCNT in the samples. The increase in $S_{\mathrm{BET}}$ for BSCF-MWCNT composites is mainly due to the increase of the micropores surface area. However, the Langmuir surface areas indicate a slightly different result since it is calculated on an area covered by one layer of gas. BSCF-MWCNT composites have a greater tendency of adsorption as the strength of a porous material depends directly on the total pore volume.

\subsection{Electrochemical Impedance Analysis}

EIS measures the impedance of a system (Z) as a function of frequency of an applied perturbation. Nyquist plot (imaginary component $\left(Z_{\text {im }}\right)$ vs. real component $\left(Z_{\text {re }}\right)$ ) explains the frequency dependence of electrode/electrolyte in the system. It combines three components, namely the electrolyte resistance between working and reference electrodes $\left(\mathrm{R}_{\mathrm{e}}\right)$, the double-layer capacitance $\left(\mathrm{C}_{\mathrm{dl}}\right)$ and the Faradaic impedance due to the charge-transfer process $\left(Z_{f}\right)$ at the working electrode-electrolyte interface. $Z_{\mathrm{f}}$ is normally subdivided into a charge-transfer resistance $\left(\mathrm{R}_{\mathrm{ct}}\right)$ and the so-called Warburg Impedance $\left(\mathrm{Z}_{\mathrm{w}}\right)$, which reflects the influence of the mass transport of the electroactive species on the total impedance of the electrochemical cell. Figure 4(a) indicates that charge transfer resistance $\left(\mathrm{R}_{\mathrm{ct}}\right)$ is only predominant in BSCF. It decreases as the amount of MWCNT is increased in the composites. Overall, the electrode process of the composite paste electrode is a diffusion limiting process. However, for MWCNT at lower frequencies, the imaginary part of the impedance increases and approaches that of an ideal capacitor. A slight variation from the ideal capacitive behaviour could be attributed to the pore size distribution of MWCNT. The loading of the BSCF has increased the conductivity of the composite where the imaginary part of the impedance for BSCF-MWCNT composite has lower value than of MWCNT.

Figure 4(b) shows that BSCF-MWCNT 70:30 has almost ideal capacitor behaviour, often known as a constant phase element (CPE) which is caused by the porosity of the electrode [39]. On the contrary, the BSCF electrode shows resistive behaviour at low frequencies which changes to capacitive behaviour at high frequencies. The BSCF-MWCNT composites exhibit capacitive behaviour at all frequencies with the BSCF-MWCNT of 70:30 w/W is the best. Figure 4(c) clearly reveals the presence of two distinguishable frequency-dependent segments on BSCF-MWCNT composites suggesting a two-step reaction closer to each other. The high-frequency region can be related to the fast charging/discharging process at the electrode/electrolyte interface, and the low-frequency region corresponds to the slow reaction process [40]. Therefore the BSCF-MWCNT composite paste electrodes have two CPEs.

Table 1. The pore parameters of the electrodes.

\begin{tabular}{|c|c|c|c|c|c|c|}
\hline Electrodes & $\mathrm{S}_{\mathrm{BET}} / \mathrm{m}^{2} \mathrm{~g}^{-1}$ & $\begin{array}{l}\text { Pore size } \\
\left(D_{w}\right) / n m\end{array}$ & $\begin{array}{l}\text { Adsorption pore } \\
\text { diameter/nm }\end{array}$ & $\begin{array}{l}\text { Desorption pore } \\
\text { diameter/nm }\end{array}$ & $\begin{array}{c}\text { Pore } \\
\text { volume } / \mathrm{cm}^{3} \mathrm{~g}^{-1}\end{array}$ & $\begin{array}{l}\text { Langmuir surface } \\
\text { area } / \mathrm{m}^{2} \mathrm{~g}^{-1}\end{array}$ \\
\hline BSCF & 14.4 & 4.5 & 1.8 & 1.4 & 0.016 & 42.6 \\
\hline BSCF-MWCNT & 58.8 & 2.7 & 2.3 & 2.5 & 4.04 & 95.86 \\
\hline
\end{tabular}




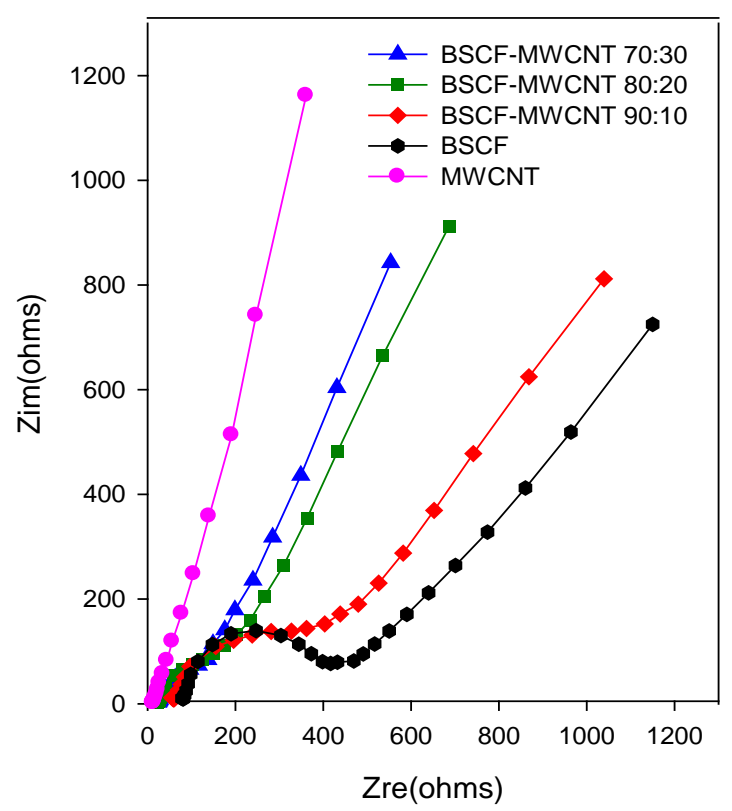

(a)

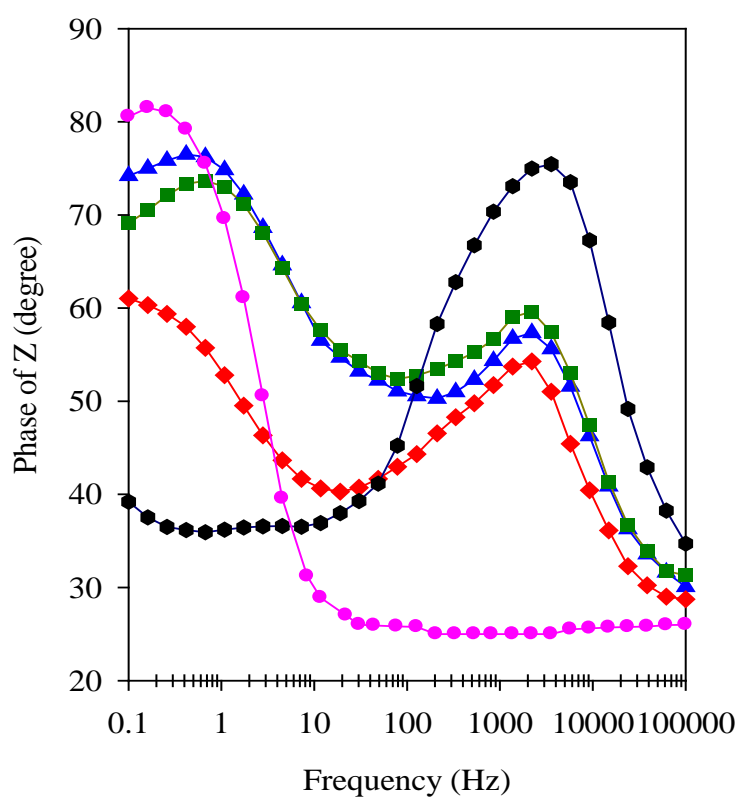

(c)

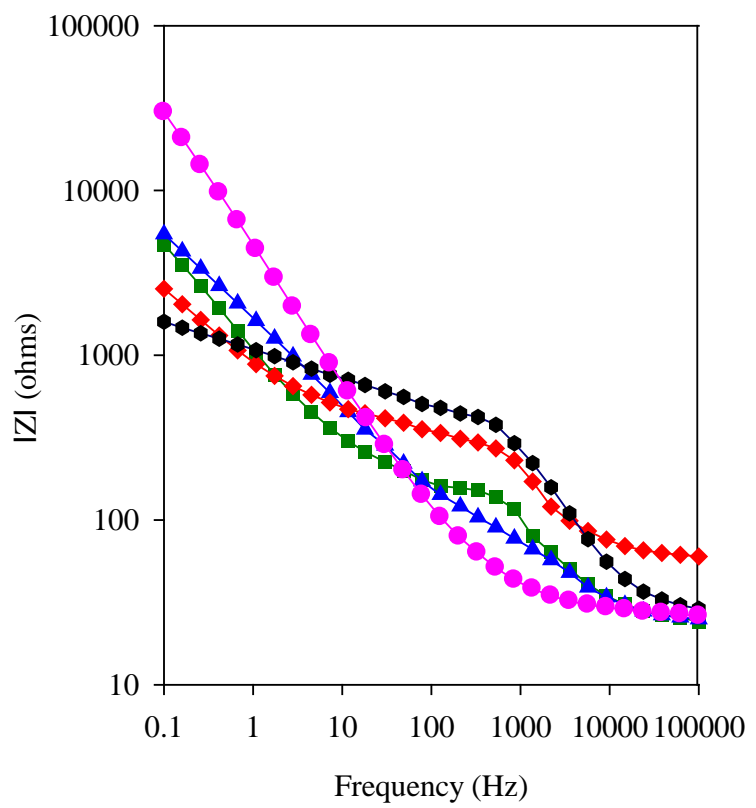

(b)
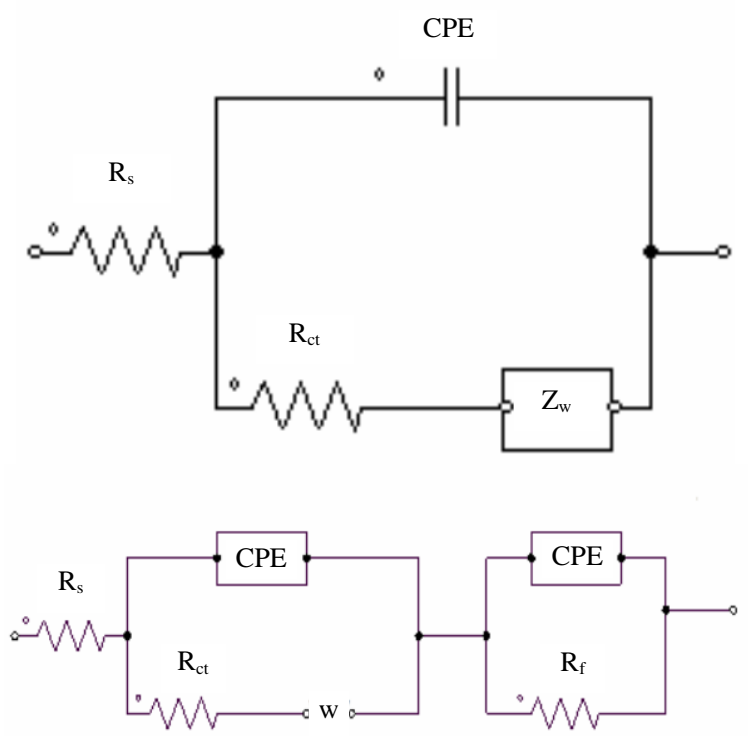

(d)

Figure 4. (a) Nyquist plots, (b) Bode magnitude, (c) Bode phase and (d) Modified Randles equivalent electrical circuit obtained for the BSCF, MWCNT, BSCF-MWCNT 90:10, 80:20 and 70:30 in $5 \mathrm{mM}\left[\mathrm{Fe}(\mathrm{CN})_{6}\right]^{4-/ 3-}$ and $0.1 \mathrm{M} \mathrm{KCl}$ at amplitude of a.c voltage of $5 \mathrm{mV}$.

In Randles equivalent circuit (Figure 4(d)) the BSCF and BSCF-MWCNT composites electrodes are fitted with the model where the capacitors have been replaced with CPEs. The best fit circuit changes from $\mathrm{R}(\mathrm{C}(\mathrm{RW}))$ for BSCF to $\mathrm{R}(\mathrm{Q}(\mathrm{RW}))(\mathrm{CR})$ for the BSCF-MWCNT electrode. The electron transfer processes at the interfacial layer of BSCF-MWCNT are facile since the apparent standard rate constant $\left(\mathrm{k}_{\mathrm{app}}\right)$ value [41] is greater by almost three fold (Table 2). This also shows that $\mathrm{R}_{\mathrm{ct}}$ of BSCF-MWCNT decreases as more MWCNT is added into the composites. Though the decrease in $\mathrm{R}_{\mathrm{ct}}$ is obvious for all the modified electrodes, the value seems less ideal compared to the MWCNT due to the imperfect coverage of the MWCNT in the composites. The bulk solution resistance $\left(R_{s}\right)$ is found to be small and shows little variation for all the electrodes. Meanwhile, there is no variation 
Table 2. Various parameters of BSCF, MWCNT and BSCF-MWCNT electrodes.

\begin{tabular}{cccccc}
\hline Electrodes & $\mathrm{R}_{s} / \Omega \mathrm{cm}^{2}$ & $\mathrm{CPE} / \Omega^{-1} \mathrm{~cm}^{-1} \mathrm{~S}^{\mathrm{n}}$ & $\mathrm{n}$ & $\mathrm{R}_{\mathrm{c}} / \Omega \mathrm{cm}^{2}$ & $\mathrm{~K}_{\mathrm{app}} / \mathrm{cms}^{-1}$ \\
\hline BSCF & 82.12 & 0.0001518 & 0.71 & 367.9 & $1.46 \times 10^{-6}$ \\
MWCNT & 18.82 & 0.0002260 & 0.80 & 98.73 & $4.82 \times 10^{-6}$ \\
BSCF-MWCNT 90:10 & 63.87 & 0.0005446 & 0.63 & 218.0 & $3.13 \times 10^{-6}$ \\
BSCF-MWCNT 80:20 & 22.71 & 0.0002496 & 0.67 & 157.0 & $3.84 \times 10^{-6}$ \\
BSCF-MWCNT 70:30 & 25.65 & 0.0003789 & 0.68 & 140.1 & $3.98 \times 10^{-6}$ \\
\hline
\end{tabular}

in the value of non ideality of the capacitor, n, which indicates the metal-solution reaction near to ideal capacitor. Therefore, it can be concluded that the MWCNT has enhanced the rate of the $\left[\mathrm{Fe}(\mathrm{CN})_{6}\right]^{4-/ 3-}$ in BSCF-MWCNT.

By using Equation (1) [41], the respective surface coverage $(\theta)$ of the BSCF-MWCNT (90:10), BSCFMWCNT (80:20) and BSCF-MWCNT (70:30) paste electrodes are 0.41, 0.58, and 0.62. This shows that the composites with a higher ratio MWCNT are better.

$$
\theta=1-\frac{R_{c t}^{\text {modified electrode }}}{R_{c t}^{\text {bare electrode }}}
$$

Exchange current $\left(i_{0}\right)$ is also used as a measure of the rate of electron transfer on BSCF and BSCF-MWCNT composites electrode. The $i_{0}$ of electrode system is given by Equation (2)

$$
i_{0}=\frac{R T}{n F R_{c t}}
$$

where $R, F$ and $n$ are gas constant, Faraday constant and number of electron transferred, respectively. The $i_{0}$ values for the redox reaction of $\left[\mathrm{Fe}(\mathrm{CN})_{6}\right]^{-3 / 4}$ on BSCF, BSCF-MWCNT (90:10), BSCF-MWCNT (80:20) and BSCF-MWCNT (70:30) are $9.83 \times 10^{-5}, 1.87 \times 10^{-4}, 2.44 \times 10^{-4}$, and $2.52 \times 10^{-4}$, respectively. It can be deduced that the rate of electron transfer is faster with the presence of MWCNT. Hence, the catalytic effect is due to enhanced surface area and conductivity.

\subsection{Cyclic Voltammetry}

There is no obvious redox by $\left[\mathrm{Fe}(\mathrm{CN})_{6}\right]^{3-}$ shown at BSCF electrodes but the cyclic voltammogram (CV) indicates that there is a capacitive behaviour (Figure 5(a)). But, the gradual increase of peak currents $\left(\mathrm{I}_{\mathrm{p}}\right)$ as the increase of MWCNT loading in the composite paste electrodes implies that the catalytic affects as well as kinetic properties of the electrode. This is due to larger specific surface area in the presence of MWCNT, which provides sufficient reaction sites for enhancing the rate of the electron transfer.

Peak separations $\left(\Delta \mathrm{E}_{\mathrm{p}}\right)$ for all composites prepared have converged to the theoretical value $(59 \mathrm{mV})$ according to the Nernst equation which shows excellent reversibility. The BSCF-MWCNT (70:30) has exhibited the most reversible among these electrodes even when compared to the pure MWCNT. To further investigate the characteristics of BSCF-MWCNT/GCE electrode surface, the effect of scan rates on the voltammetric behaviour ofBSCF-MWCNT (70:30) is examined. The results obtained (Figure 5(b)) show the redox peak currents increase linearly with scan rates, which indicates that the redox process is confined to the surface of BSCFMWCNT (70:30) electrode, confirming that the electrode is stable. The redox peak currents show linear behaviour with the square root of the scan rate, $v^{1 / 2}$ (Inset: Figure 5(b)) revealing that the electron-transfer process is a diffusion controlled [42]. Hence it is obvious that the BSCF-MWCNT (70:30) electrodes possess faster chargetransfer kinetics which is attributed to the presence of MWCNT as a modifier.

\subsection{Oxygen Reduction Behaviour}

From Figure 6 compares oxygen reduction behaviour of the BSCF-MWCNT (70:30), BSCF and MWCNT electrodes $0.1 \mathrm{M} \mathrm{KOH}$ saturated with oxygen. The BSCF-MWCNT (70:30) exhibits greatly enhanced catalytic activity towards the electrochemical reduction of $\mathrm{O}_{2}$. The onset potential of ORR is positively shifted by 400 


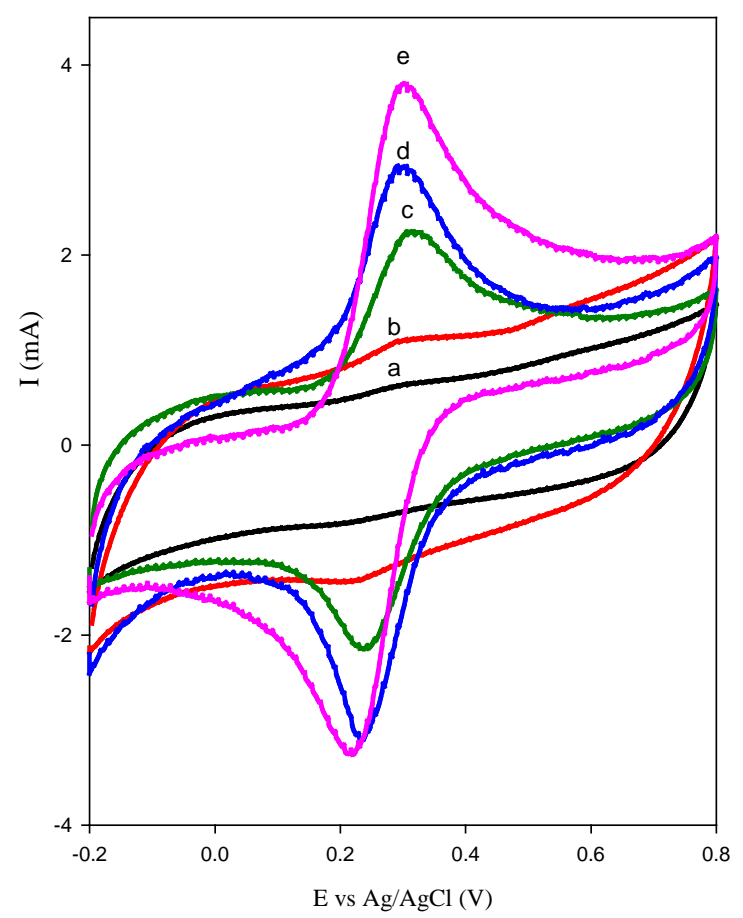

(a)

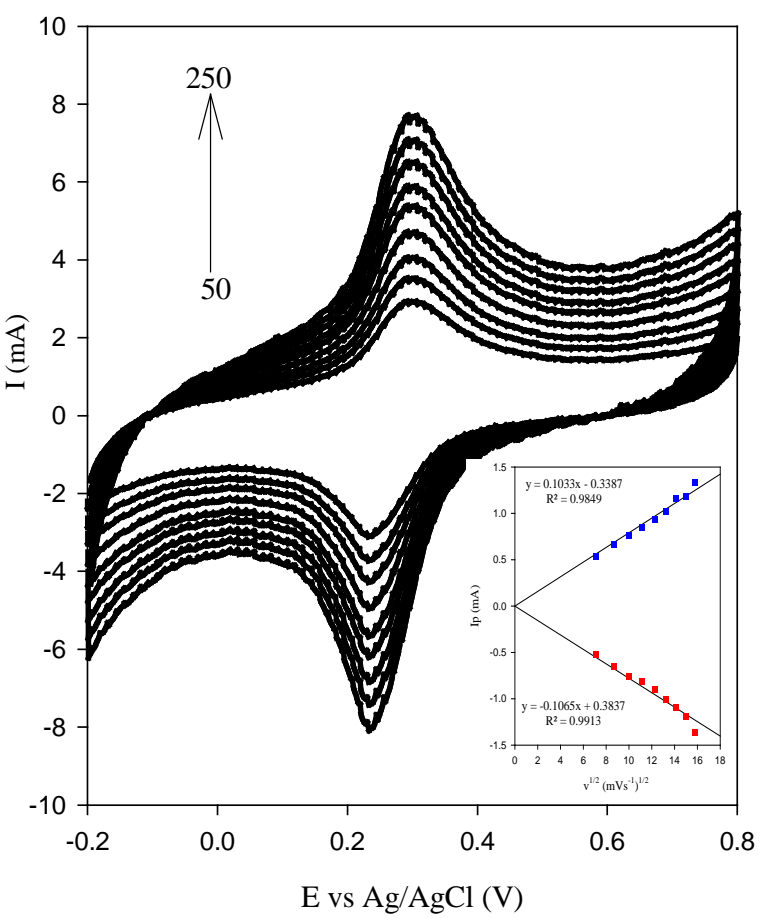

(b)

Figure 5. (a) $\mathrm{CV}$ of $5 \mathrm{mM} \mathrm{K}_{4}\left[\mathrm{Fe}(\mathrm{CN})_{6}\right]$ in $0.1 \mathrm{MKCl}$ at (a) BSCF, (b) BSCF-MWCNT 90:10, (c) BSCF-MWCNT 80:20, (d) BSCF-MWCNT 70:30) and (e) MWCNT; (b) CV scans of BSCF-MWCNT 70:30 recorded at different scan rates (Inset: linear relationship in peak current $v$ s. the square root of scan rate).

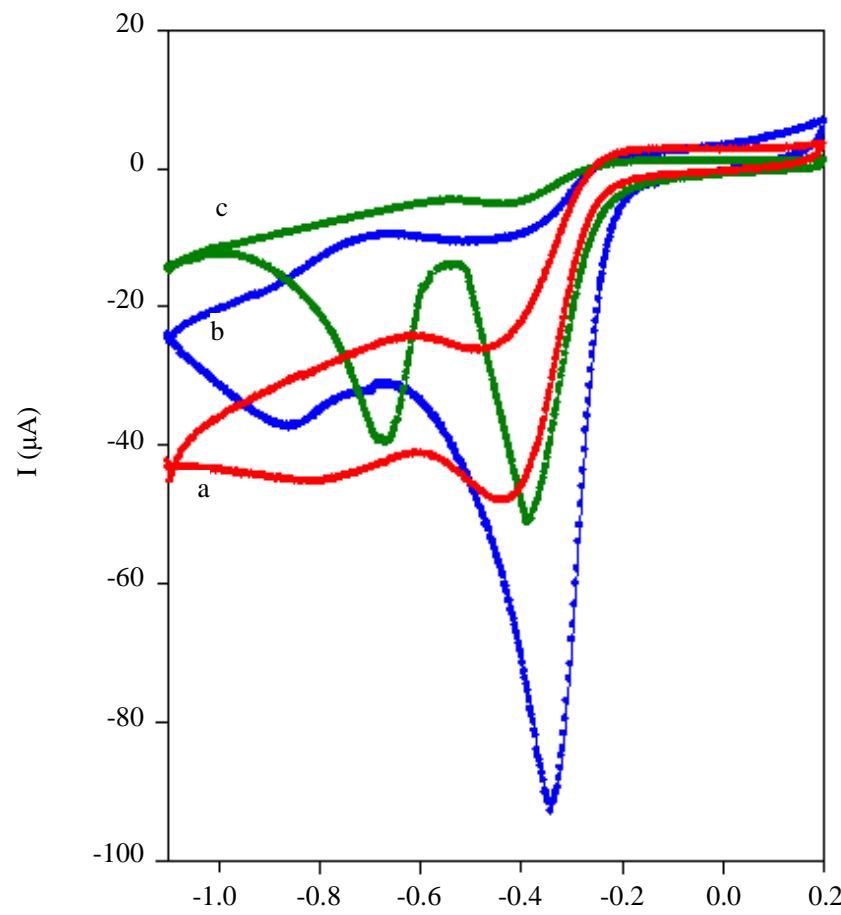

E vs $\mathrm{Ag} / \mathrm{AgCl}(\mathrm{V})$

Figure 6. $\mathrm{CV}$ of ORR in $0.1 \mathrm{M} \mathrm{KOH}$ at $25^{\circ} \mathrm{C}$ of (a) BSCF, (b) BSCF-MWCNT 70:30 and (c) MWCNT electrodes. 
$\mathrm{mV}$ on the BSCF-MWCNT (70:30) as compared with that for BSCF electrode. Moreover, the cathodic peak current $\left(\mathrm{I}_{\mathrm{pc}}\right)$ has increased four fold which is attribute to the larger specific surface area caused by the higher surface-to-volume ratio. Two irreversible peak currents are observed at MWCNT electrode. The $\mathrm{I}_{\mathrm{pc}}$ at the low overpotential is attributed to $2 \mathrm{e}^{-}$reduction to $\mathrm{H}_{2} \mathrm{O}_{2}$ and at more negative potentials the peroxide intermediate is further reduced. However, for BSCF and BSCF-MWCNT (70:30) electrodes, only one peak is observed. Such catalytic effect can be explained by the high affinity of the BSCF towards oxygen.

The effect of $\mathrm{pH}$ on the oxygen reduction reaction (ORR) potential at BSCF-MWCNT (70:30) is shown (Figure 7). There is no significant reduction observed at $\mathrm{pH} 1$ which probably due to the decomposition of $\mathrm{O}_{2}$. However, as the $\mathrm{pH}$ is increased, reduction peak potential $\left(\mathrm{E}_{\mathrm{pc}}\right)$ of $\mathrm{O}_{2}$ is shifted positively and the $\mathrm{I}_{\mathrm{pc}}$ increases. Only one $\mathrm{E}_{\mathrm{pc}}$ is produced in an acidic media indicating irreversibility. On the contrary, there are two pairs of redox peaks observed in a basic media. Overall, the reduction peaks are more dominant with the smaller peak become less important due to its more negative value and usually bypassed by catalysing the $\mathrm{HO}_{2}^{-}$decomposition. Depending on the electrode material and its surface properties as well as the solution $\mathrm{pH}$, two steps for ORR are anticipated; it is either via a direct four electrons (Equation (3)) or an indirect two step two electrons mechanism leading to water (Equations (4) and (5)):

$$
\begin{aligned}
& \mathrm{O}_{2}+4 \mathrm{H}^{+}+4 \mathrm{e}^{-} \rightarrow 2 \mathrm{H}_{2} \mathrm{O} \\
& \mathrm{O}_{2}+2 \mathrm{H}^{+}+2 \mathrm{e}^{-} \rightarrow \mathrm{H}_{2} \mathrm{O}_{2} \\
& \mathrm{H}_{2} \mathrm{O}_{2}+2 \mathrm{H}^{+}+2 \mathrm{e}^{-} \rightarrow 2 \mathrm{H}_{2} \mathrm{O}
\end{aligned}
$$

The larger peak is attributed to the reduction of oxygen to hydrogen peroxide and the minor peak is the reduction to water. The change in the redox peak potential that occurs with the change of $\mathrm{pH}$ is attributed to the reaction involving the surface adsorbed species. As the electrocatalysis is minimized as the $\mathrm{pH}$ is increased (with less $\mathrm{H}^{+}$available), it is concluded that the mechanism of ORR is a $\mathrm{H}_{3} \mathrm{O}^{+}$-dependent process in an acidic medium and is predominantly $\mathrm{OH}^{-}$based in alkaline medium. Generally, the best catalytic activity is observed in $\mathrm{pH} 12$.

The CV of the BSCF-MWCNT (70:30) in the presence and absence of oxygen is included in Figure 8(a). It shows that there is a large enhancement of $\mathrm{I}_{\mathrm{pc}}$ at $\mathrm{E}_{\mathrm{pc}}=-0.37 \mathrm{~V}$ in the presence of $\mathrm{O}_{2}$. A linear relationship in peak current vs the square root of the scan rate (Figure 8(b)) supports that the $\mathrm{O}_{2}$ reaction is related only to the diffusion rate of $\mathrm{O}_{2}$ from solution to the surface of the BSCF-MWCNT electrode. It also means that $\mathrm{O}_{2}$ will be

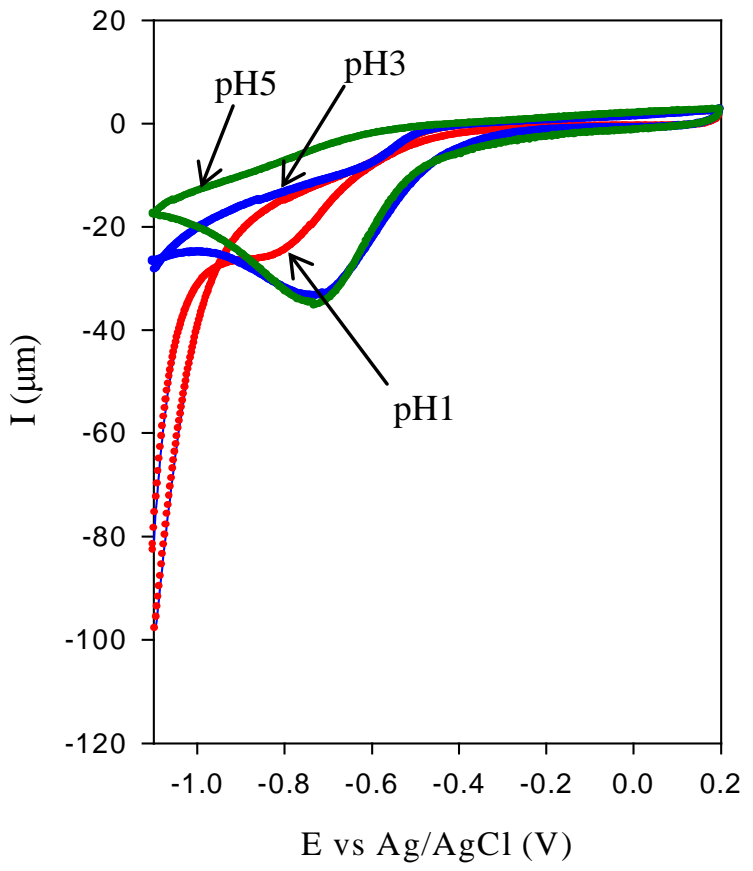

(a)

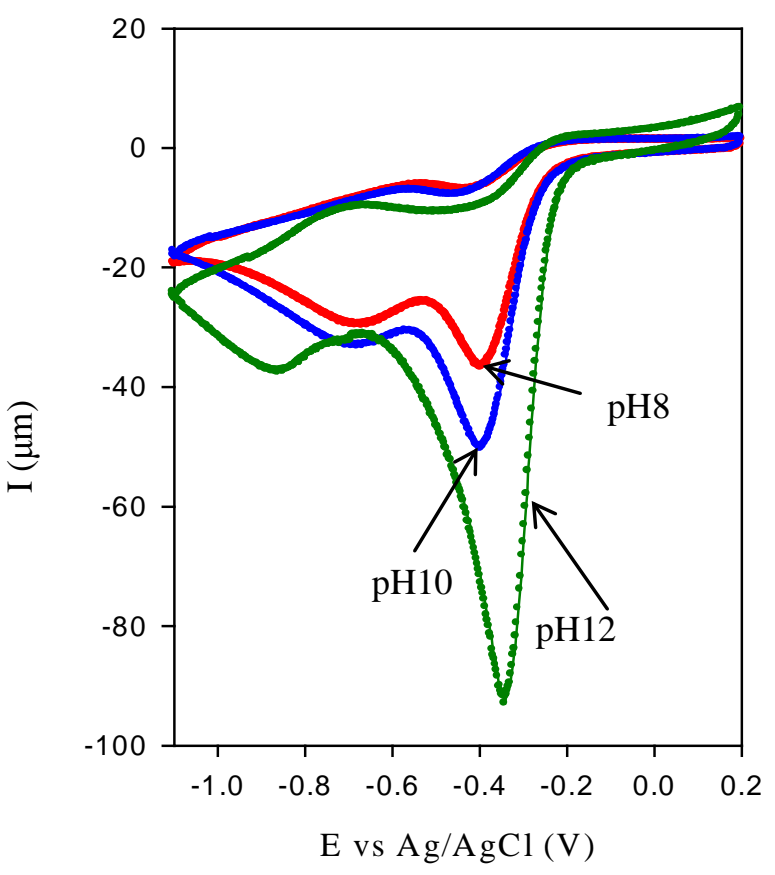

(b)

Figure 7. CV of oxygen reduction at BSCF-MWCNT 70:30 electrode in acid (A) and in basic (B) media at $25^{\circ} \mathrm{C}$. 


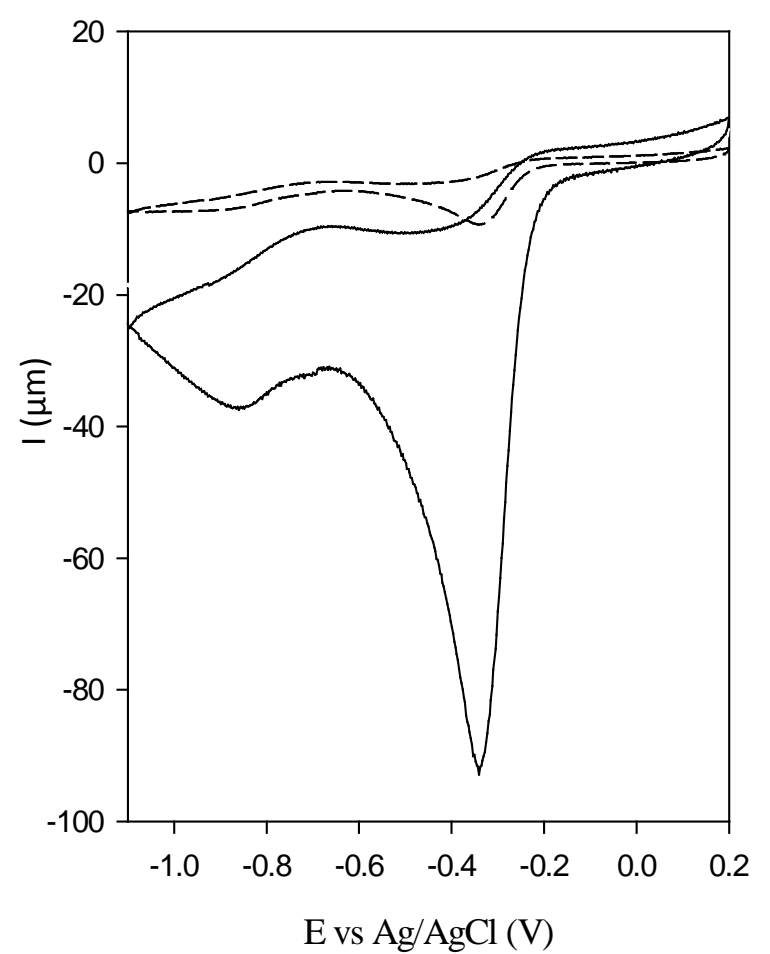

(a)

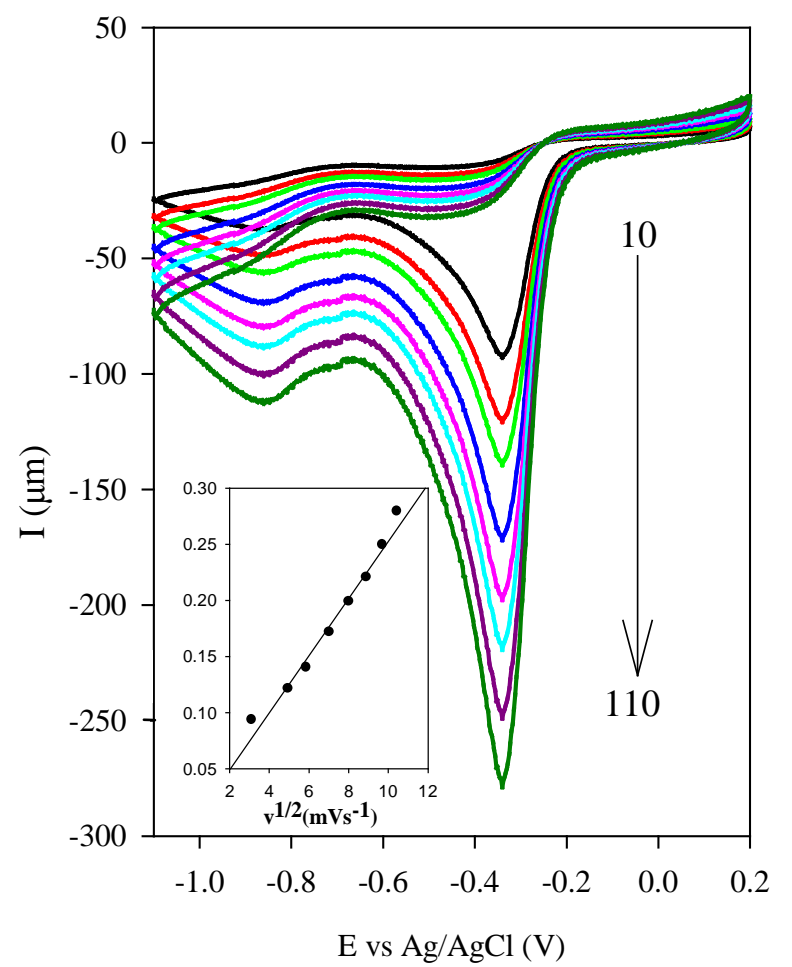

(b)

Figure 8. (a) CV of BSCF-MWCNT 70:30 with absence (dotted line) and presence (solid line) of $\mathrm{O}_{2}$ in $0.1 \mathrm{M} \mathrm{KOH}$ and (b) CV scans of BSCF-MWCNT 70:30 at pH 12 recorded at different scan rates (Inset: linear relationship in peak current vs. the square root of the scan rate).

detached from the BSCF-MWCNT electrode.

\section{Conclusion}

A simple BSCF-MWCNT electrode has been prepared and optimized for ORR at pH 12. It has exhibited an excellent electrocatalytic activity towards ORR at the room temperature. The higher ratio of MWCNT in the composites is vital for better electrocatalysis. The MWCNT, the modifier material, has improved the performance of the BSCF on its charge-transfer, conductivity, oxygen adsorption and reduction. The application of BSCFMWCNT electrode as a cathode for ORR in a fuel cell is then proposed. This is the subject for the next report.

\section{Acknowledgements}

This work was supported by the Ministry of Higher Education (MHE) Fundamental Research Grant Scheme (FRGS) No. 203/PKIMIA/6711263 and Universiti Sains Malaysia Incentive Postgraduate Grant, 1001/PKIMIA/ 821014. One of the authors (FY) would like to thank Universiti Malaysia Terengganu, Malaysia for the study leave rendered.

\section{References}

[1] Babcock, G.T. and Wikström, M. (1992) Oxygen Activation and the Conservation of Energy in Cell Respiration. Nature, 356, 301-309. http://dx.doi.org/10.1038/356301a0

[2] Kendig, M. and Jeanjaquet, S. (2002) Cr (VI) and Ce (III) Inhibition of Oxygen Reduction on Copper. Journal of the Electrochemical Society, 149, B47-B51. http://dx.doi.org/10.1149/1.1430717

[3] Nørskov, J.K., Rossmeisl, J., Logadottir, A., et al. (2004) Origin of the Overpotential for Oxygen Reduction at a Fuel-Cell Cathode. The Journal of Physical Chemistry B, 108, 17886-17892. http://dx.doi.org/10.1021/jp047349j

[4] Schmidt, T., Paulus, U., Gasteiger, H., et al. (2001) The Oxygen Reduction Reaction on a Pt/Carbon Fuel Cell Catalyst in the Presence of Chloride Anions. Journal of Electroanalytical Chemistry, 508, 41-47. 
http://dx.doi.org/10.1016/S0022-0728(01)00499-5

[5] Srivastava, R., Mani, P., Hahn, N., et al. (2007) Efficient Oxygen Reduction Fuel Cell Electrocatalysis on Voltammetrically Dealloyed Pt-Cu-Co Nanoparticles. Angewandte Chemie International Edition, 46, 8988-8991. http://dx.doi.org/10.1002/anie.200703331

[6] Qu, L., Liu, Y., Baek, J.-B., et al. (2010) Nitrogen-Doped Graphene as Efficient Metal-Free Electrocatalyst for Oxygen Reduction in Fuel Cells. ACS Nano, 4, 1321-1326. http://dx.doi.org/10.1021/nn901850u

[7] Fernández, J.L., Raghuveer, V., Manthiram, A., et al. (2005) Pd-Ti and Pd-Co-Au Electrocatalysts as a Replacement for Platinum for Oxygen Reduction in Proton Exchange Membrane Fuel Cells. Journal of the American Chemical Society, 127, 13100-13101. http://dx.doi.org/10.1021/ja0534710

[8] Mukerjee, S. and Srinivasan, S. (1993) Enhanced Electrocatalysis of Oxygen Reduction on Platinum Alloys in Proton Exchange Membrane Fuel Cells. Journal of Electroanalytical Chemistry, 357, 201-224. http://dx.doi.org/10.1016/0022-0728(93)80380-Z

[9] Zhang, J., Sasaki, K., Sutter, E., et al. (2007) Stabilization of Platinum Oxygen-Reduction Electrocatalysts Using Gold Clusters. Science, 315, 220-222. http://dx.doi.org/10.1126/science.1134569

[10] Zhao, F., Harnisch, F., Schröder, U., et al. (2005) Application of Pyrolysed Iron (II) Phthalocyanine and CoTMPP Based Oxygen Reduction Catalysts as Cathode Materials in Microbial Fuel Cells. Electrochemistry Communications, 7, 1405-1410. http://dx.doi.org/10.1016/j.elecom.2005.09.032

[11] Yeager, E. (1984) Electrocatalysts for $\mathrm{O}_{2}$ Reduction. Electrochimica Acta, 29, 1527-1537. http://dx.doi.org/10.1016/0013-4686(84)85006-9

[12] Collman, J.P., Denisevich, P., Konai, Y., et al. (1980) Electrode Catalysis of the Four-Electron Reduction of Oxygen to Water by Dicobalt Face-to-Face Porphyrins. Journal of the American Chemical Society, 102, 6027-6036. http://dx.doi.org/10.1021/ja00539a009

[13] Maricle, D. and Hodgson, W. (1965) Reducion of Oxygen to Superoxide Anion in Aprotic Solvents. Analytical Chemistry, 37, 1562-1565. http://dx.doi.org/10.1021/ac60231a027

[14] Damjanovic, A. and Brusic, V. (1967) Electrode Kinetics of Oxygen Reduction on Oxide-Free Platinum Electrodes. Electrochimica Acta, 12, 615-628. http://dx.doi.org/10.1016/0013-4686(67)85030-8

[15] Ishihara, T., Kudo, T., Matsuda H., et al. (1995) Doped $\mathrm{PrMnO}_{3}$ Perovskite Oxide as a New Cathode of Solid Oxide Fuel Cells for Low Temperature Operation. Journal of the Electrochemical Society, 142, 1519-1524. http://dx.doi.org/10.1149/1.2048606

[16] Xie, Z., Zhao, H., Du, Z., et al. (2012) Effects of Co Doping on the Electrochemical Performance of Double Perovskite Oxide $\mathrm{Sr}_{2} \mathrm{MgMoO}_{6-\delta}$ as an Anode Material for Solid Oxide Fuel Cells. The Journal of Physical Chemistry C, 116, 9734-9743. http://dx.doi.org/10.1021/jp212505c

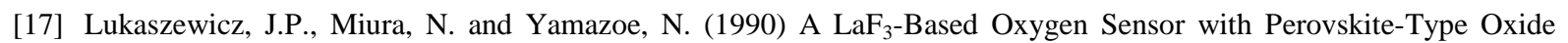
Electrode Operative at Room Temperature. Sensors and Actuators B: Chemical, 1, 195-198.

http://dx.doi.org/10.1016/0925-4005(90)80199-A

[18] Lukaszewicz, J.P., Miura, N. and Yamazoe, N. (1989) Application of Perovskite-Type Oxides to the Sensing Electrode of a $\mathrm{LaF}_{3}$-Based Oxygen Sensor Workable at Room Temperature. Japanese Journal of Applied Physics, 28, L711L713. http://dx.doi.org/10.1143/JJAP.28.L711

[19] Esaka, T., Morimoto, H. and Iwahara, H. (1992) Nonstoichiometry in Perovskite-Type Oxide $\mathrm{Ca}_{1-\mathrm{x}} \mathrm{Ce}_{\mathrm{x}} \mathrm{MnO}_{3-\delta}$ and Its Properties in Alkaline Solution. Journal of Applied Electrochemistry, 22, 821-824. http://dx.doi.org/10.1007/BF01023724

[20] Suntivich, J., Gasteiger, H.A., Yabuuchi, N., et al. (2011) Design Principles for Oxygen-Reduction Activity on Perovskite Oxide Catalysts for Fuel Cells and Metal-Air Batteries. Nature Chemistry, 3, 546-550. http://dx.doi.org/10.1038/nchem.1069

[21] Suntivich, J., May, K.J., Gasteiger, H.A., et al. (2011) A Perovskite Oxide Optimized for Oxygen Evolution Catalysis from Molecular Orbital Principles. Science, 334, 1383-1385. http://dx.doi.org/10.1126/science.1212858

[22] Balasubramanian, K. and Burghard, M. (2006) Biosensors Based on Carbon Nanotubes. Analytical and Bioanalytical Chemistry, 385, 452-468. http://dx.doi.org/10.1007/s00216-006-0314-8

[23] Wang, J. and Musameh, M. (2003) Carbon Nanotube/Teflon Composite Electrochemical Sensors and Biosensors. Analytical Chemistry, 75, 2075-2079. http://dx.doi.org/10.1021/ac030007+

[24] Jiang, L., Wang, R., Li, X., et al. (2005) Electrochemical Oxidation Behavior of Nitrite on a Chitosan-Carboxylated Multiwall Carbon Nanotube Modified Electrode. Electrochemistry Communications, 7, 597-601. http://dx.doi.org/10.1016/j.elecom.2005.04.009

[25] Wang, J., Kawde, A.-N. and Musameh, M. (2003) Carbon-Nanotube-Modified Glassy Carbon Electrodes for Ampli- 
fied Label-Free Electrochemical Detection of DNA Hybridization. Analyst, 128, 912-916. http://dx.doi.org/10.1039/b303282e

[26] Fei, S., Chen, J., Yao, S., et al. (2005) Electrochemical Behavior of L-Cysteine and Its Detection at Carbon Nanotube Electrode Modified with Platinum. Analytical Biochemistry, 339, 29-35. http://dx.doi.org/10.1016/j.ab.2005.01.002

[27] Wang, J., Deo, R.P. and Musameh, M. (2003) Stable and Sensitive Electrochemical Detection of Phenolic Compounds at Carbon Nanotube Modified Glassy Carbon Electrodes. Electroanalysis, 15, 1830-1834. http://dx.doi.org/10.1002/elan.200302772

[28] Peigney, A., Laurent, C., Flahaut, E., et al. (2001) Specific Surface Area of Carbon Nanotubes and Bundles of Carbon Nanotubes. Carbon, 39, 507-514. http://dx.doi.org/10.1016/S0008-6223(00)00155-X

[29] Ma, P.C., Tang, B.Z. and Kim, J.-K. (2008) Effect of CNT Decoration with Silver Nanoparticles on Electrical Conductivity of CNT-Polymer Composites. Carbon, 46, 1497-1505. http://dx.doi.org/10.1016/j.carbon.2008.06.048

[30] Shao, Z., Yang, W., Cong, Y., et al. (2001) Investigation of the Permeation Behavior and Stability of a $\mathrm{Ba}_{0.5} \mathrm{Sr}_{0.5} \mathrm{Co}_{0.8} \mathrm{Fe}_{0.23-\delta}$ Oxygen Membrane. Journal of Membrane Science, 172, 177-188. http://dx.doi.org/10.1016/S0376-7388(00)00337-9

[31] Yang, Z., Harvey, A.S., Infortuna, A., et al. (2009) Phase Relations in the Ba-Sr-Co-Fe-O System at 1273 K in Air. Journal of Applied Crystallography, 42, 153-160. http://dx.doi.org/10.1107/S0021889809002040

[32] Mueller, D.N., De Souza, R.A., Weirich, T.E., et al. (2010) A Kinetic Study of the Decomposition of the Cubic Perovskite-Type Oxide $\mathrm{Ba}_{x} \mathrm{Sr}_{1-\mathrm{x}} \mathrm{Co}_{0.8} \mathrm{Fe}_{0.2} \mathrm{O}_{3-\delta}$ (BSCF)(x=0.1 and 0.5). Physical Chemistry Chemical Physics, 12, 10320-10328. http://dx.doi.org/10.1039/c0cp00004c

[33] Saini, P., Choudhary, V., Singh, B., et al. (2009) Polyaniline-MWCNT Nanocomposites for Microwave Absorption and EMI Shielding. Materials Chemistry and Physics, 113, 919-926. http://dx.doi.org/10.1016/j.matchemphys.2008.08.065

[34] Li, J. and Zhitomirsky, I. (2009) Electrophoretic Deposition of Manganese Dioxide-Carbon Nanotube Composites. Journal of Materials Processing Technology, 209, 3452-3459. http://dx.doi.org/10.1016/j.jmatprotec.2008.08.001

[35] Neimark, A.V. and Ravikovitch, P.I. (2001) Capillary Condensation in MMS and Pore Structure Characterization. Microporous and Mesoporous Materials, 44, 697-707. http://dx.doi.org/10.1016/S1387-1811(01)00251-7

[36] Charinpanitkul, T., Soottitantawat, A., Tonanon, N., et al. (2009) Single-Step Synthesis of Nanocomposite of Copper and Carbon Nanoparticles Using Arc Discharge in Liquid Nitrogen. Materials Chemistry and Physics, 116, 125-128. http://dx.doi.org/10.1016/j.matchemphys.2009.02.060

[37] Geng, H.-Z., Kim, T.H., Lim, S.C., et al. (2010) Hydrogen Storage in Microwave-Treated Multi-Walled Carbon Nanotubes. International Journal of Hydrogen Energy, 35, 2073-2082.

[38] López, T., Bata-García, J.L., Esquivel, D., et al. (2011) Treatment of Parkinson’s Disease: Nanostructured Sol-Gel Silica-Dopamine Reservoirs for Controlled Drug Release in the Central Nervous System. International Journal of Nanomedicine, 6, 19.

[39] Naseer, A. and Khan, A.Y. (2009) A Study of Growth and Breakdown of Passive Film on Copper Surface by Electrochemical Impedance Spectroscopy. Turkish Journal of Chemistry, 33, 739-750.

[40] Omanovic, S. and Roscoe, S.G. (2000) Interfacial Behavior of $\beta$-Lactoglobulin at a Stainless Steel Surface: An Electrochemical Impedance Spectroscopy Study. Journal of Colloid and Interface Science, 227, 452-460. http://dx.doi.org/10.1006/jcis.2000.6913

[41] Bard, A.J. and Faulkner, L.R. (1980) Electrochemical Methods: Fundamentals and Applications. Wiley, New York.

[42] Sun, W., Yang, M. and Jiao, K. (2007) Electrocatalytic Oxidation of Dopamine at an Ionic Liquid Modified Carbon Paste Electrode and Its Analytical Application. Analytical and Bioanalytical Chemistry, 389, 1283-1291. http://dx.doi.org/10.1007/s00216-007-1518-2 